\title{
Delivery of a Graduate Course in Fire Performance TESTING UsING VideOCONFERENCE TECHNOLOGY
}

\author{
David Torvi ${ }^{1}$ and Elizabeth Weckman ${ }^{2}$ \\ ${ }^{1}$ Department of Mechanical Engineering, University of Saskatchewan \\ ${ }^{2}$ Department of Mechanical and Mechatronics Engineering, University of Waterloo \\ Corresponding Author: david.torvi@usask.ca
}

\begin{abstract}
There is a growing demand for fire safety engineers. While new fire safety engineering programs have been created, the demand for highly qualified personnel is growing more rapidly than the supply of new graduates. One particular challenge is the ability of a single institution to offer the range of courses required in a comprehensive fire safety engineering program.

Fire Performance Testing and other courses in the UW Fire Safety Engineering program are offered in a modular format: lectures are given over one week, and students submit coursework over the following four to six months. This format allows a larger number of practicing engineers and faculty from other universities to take or teach courses. This paper focuses on the use of videoconference technology in ME 770. Since 2012 about half of the students, and one of the instructors, have taken the course or delivered their lectures by videoconference. Lessons learned, and efforts to establish modular fire courses with other universities, will also be discussed.
\end{abstract}

Keywords: fire safety engineering, distance learning, videoconference, modular courses, graduate studies, continuing education, fire testing, codes and standards.

\section{INTRODUCTION}

Fire safety engineers and scientists face significant challenges in providing fire protection for occupants, fire service personnel and property. These challenges have increased in recent years. Fires involving new materials, such as plastics, grow more rapidly and release more energy and toxic combustion products than fires involving traditional materials, such as wood [1,2]. To mitigate such risks, new fire performance tests and standards are being developed for use in product regulation and engineering design. It is also important for engineers to understand the suitability of existing fire tests, many of which were originally developed to evaluate wooden building materials and products. In some cases, these longstanding tests may give misleading results when used to evaluate the fire performance of newer materials, such as plastics that melt or drip when exposed to flame, as noted in the scope of the Steiner Tunnel test, which is used to determine flame spread ratings of building materials [3].

In Canada, changes to building and fire codes over the past decade have also had a significant impact on fire safety engineering. The introduction of objective-based building codes, beginning with the 2005 National Building Code of Canada [4], has increased the flexibility permitted in design of fire protection systems as compared to previous prescriptive codes. Evolving codes, materials and technologies require a continually increasing understanding of fire science by engineers, scientists, architects, and regulators. Some traditional engineering and science programs provide entry level training, but many critical skills are currently acquired via "on-the-job" experience.

Fire safety is also highly multidisciplinary, requiring thorough knowledge of a wide range of areas in engineering, natural, social and health sciences. For example, when designing a fire protection system an engineer must be able to understand and apply fundamentals of heat transfer, fluid mechanics, chemistry, combustion and solid mechanics to estimate the growth of a fire and its effects on a building. They must also be able to apply concepts from physiology and psychology to model the effects of fire and smoke on building occupants and first responders, and to understand ways in which occupants may react to fire.

Developments in materials, testing and building codes have resulted in a dramatically increased demand for trained fire safety professionals. At the same time, as is the case with many other engineering disciplines, a significant percentage of practitioners are expected to retire in the coming decade. For example, in 2010 the Society of Fire Protection Engineers (SFPE) estimated that $20 \%$ of fire safety engineers were age 55 or older [5]. Therefore, there is a critical need to train new fire safety professionals.

As part of the effort to train new fire safety engineers, there are on-going efforts to define the knowledge base necessary for fire safety professionals and to develop 
model curricula for fire safety undergraduate and graduate programs [6,7]. Examining these model curricula it is apparent that it can be difficult to access all of the required expertise in a single institution, so collaborative programs are being developed around the world. In one of these programs, the EU Erasmus Mundus MSc in Fire Safety Engineering, which began in 2010, students take courses and conduct research at the Universities of Edinburgh, Ghent and Lund [8]. In Canada, complete fire safety engineering graduate programs are offered at the University of Waterloo (UW) and Carleton University. Individual fire safety engineering courses are offered at University of Saskatchewan (UofS) and Concordia University. Fire science research is conducted at these four universities, as well as other universities and the National Research Council.

This paper will first outline the UW Fire Safety Engineering graduate program. Courses are offered in a modular format, which has allowed faculty from other universities and organizations to participate in offering courses, and students from across Canada to take courses. The paper will then focus on one course in the program, ME 770, and the use of videoconference technology in offering this course. Lessons learned over the past two years, and efforts to increase the number of fire safety engineering courses offered in Canada, are also discussed.

\section{UW FIRE SAFETY ENGINEERING GRADUATE PROGRAM}

UW offers M.Eng., M.A.Sc. and Ph.D. graduate programs in fire safety engineering. Students may also take UW graduate courses as part of a certificate program, or individually as part of another graduate program or their continuing professional education. The program offers six courses annually, which are taught by UW faculty, and adjuncts and other faculty from universities in Canada, the US and Europe (Table 1). Involving faculty from other universities has allowed the program to offer students an opportunity to complete all of their required coursework in the fire safety area, as compared to many fire science graduate programs offered through mechanical engineering or other departments, where students may only have an opportunity to complete one or two fire safety engineering courses. The Fire Safety Engineering graduate program began in 2007. Between 2007 and 2013, there were 16 M.Eng., 15 M.A.Sc. and 6Ph.D. students registered in the program. Forty-seven other students took individual courses as professional development students or as part of another graduate program (e.g., a M.A.Sc. in civil engineering).
Table 1: University of Waterloo Fire Safety Engineering Graduate Courses.

\begin{tabular}{|l|l|}
\hline Course & Instructor(s) \\
\hline Fire Dynamics & Weckman (Waterloo) \\
\hline $\begin{array}{l}\text { Fire Performance } \\
\text { Testing }\end{array}$ & $\begin{array}{l}\text { Torvi (Saskatchewan) } \\
\text { Weckman (Waterloo) }\end{array}$ \\
\hline Fire Risk & $\begin{array}{l}\text { Watts (Fire Safety Institute) } \\
\text { Jomaas (Tech. U. of Denmark) }\end{array}$ \\
\hline Fire Resistance & Kodur (Michigan State) \\
\hline Fire Modelling & $\begin{array}{l}\text { Inal (Waterloo) } \\
\text { Weckman (Waterloo) }\end{array}$ \\
\hline $\begin{array}{l}\text { Advanced Enclosure } \\
\text { Fire Dynamics }\end{array}$ & Strong (Waterloo) \\
\hline
\end{tabular}

Since its inception, all of the courses in the program have been offered in a modular format. Lectures are held over a one week period, and assignments, and laboratory and project reports are handed in over a four to six month period in the following term. This format was chosen to allow students from industry to attend courses, and faculty from other universities to teach in the program. During the first several years, faculty and practically all of the students came to Waterloo for the courses (a few students took these as reading courses). Over the past two years videoconference technology has been utilized, and in a typical course, about half of the students participate using this technology. However, practically all students will attend lectures in person for at least one of their courses.

\section{ME 770 FIRE PERFORMANCE TESTING}

The objective of ME 770 is to introduce students to the theory, practice and hands-on aspects of fire test methods. Major topics covered during the lectures and course readings are listed in Table 2 . One particular emphasis of the course is to equip students to design fire experiments, which will assist them in their thesis research and professional practice. Therefore, about one day of lectures is spent on experimental design principles and the main instrumentation used in fire science. The key standard tests used in fire safety engineering are also covered, including their history and limitations. 
Table 2: ME 770 Course Outline.

\begin{tabular}{|c|c|c|}
\hline & Sections & Major Topics \\
\hline 1 & Introduction & $\begin{array}{l}\text { - historical basis of fire tests } \\
\text { - role of fire testing in design, } \\
\text { codes and standards }\end{array}$ \\
\hline 2 & $\begin{array}{l}\text { Experimental } \\
\text { Design }\end{array}$ & $\begin{array}{l}\text { - design of fire experiments } \\
\text { - measurement (temperature, heat } \\
\text { flux, and velocity) }\end{array}$ \\
\hline 3 & $\begin{array}{l}\text { Heat Release } \\
\text { Rate (HRR) } \\
\text { Tests }\end{array}$ & $\begin{array}{l}\text { - fire dynamics and calorimetry } \\
\text { - small and full-scale HRR tests } \\
\text { - combustion gas analysis } \\
\text { - case studies }\end{array}$ \\
\hline 4 & $\begin{array}{l}\text { Ignition \& } \\
\text { Flammability } \\
\text { Tests }\end{array}$ & $\begin{array}{l}\text { - ignition theory } \\
\text { - small-scale flammability tests } \\
\text { - full-scale flame spread tests } \\
\text { (Steiner Tunnel, exterior wall) }\end{array}$ \\
\hline 5 & $\begin{array}{l}\text { Fire Resistance } \\
\text { Tests }\end{array}$ & $\begin{array}{l}\text { - full-scale wall and floor tests } \\
\text { - fire resistance models }\end{array}$ \\
\hline 6 & $\begin{array}{l}\text { Fire } \\
\text { Experiments \& } \\
\text { Reconstruction } \\
\text { S } \\
\end{array}$ & $\begin{array}{l}\text { - design of field fire tests } \\
\text { - case studies, collaborations } \\
\text { with fire departments and } \\
\text { agencies } \\
\end{array}$ \\
\hline 7 & Textile Tests & $\begin{array}{l}\text { - textile flammability tests } \\
\text { - protective clothing tests } \\
\text { - test standard development }\end{array}$ \\
\hline 8 & Friday Forum & - student project presentations \\
\hline
\end{tabular}

Another emphasis of the course is to assist students in developing their ability to critically evaluate test results. The course project requires students to select a standard fire test or a series of experiments of interest to their thesis research or professional practice. Students are expected to describe the history of the test, the equipment used, and the principles of operation. They are also expected to identify current issues surrounding the test, including technical, political and economic issues, which often impact standard development. The major part of the project is a critical discussion of the strengths and weaknesses of the test and how well it simulates the actual fire behaviour of the material being tested.

Students (both on campus and remote) make an initial presentation on the fire test of their choice on the Friday of the week of lectures (worth $10 \%$ of the final grade). As many of the students from industry use the particular standard test they have chosen on a regular basis in design, this allows other students to gain additional insight into the role of fire testing in engineering practice. Students receive feedback on their selected topic from the instructors and students, and incorporate this feedback into their formal project proposal, which is due two weeks after the lectures end (10\% of final grade). The project report is due at the end of the term (30\% of final grade).

In addition to the lectures, laboratory sessions are also scheduled during the week of lectures. In 2013, tests were conducted using the UW cone calorimeter (Fig. 1) and Steiner Tunnel (Fig. 2). The teaching assistant used a web camera to broadcast the laboratory sessions for those who could not attend in person. Students were supplied with test data, photographs and video from these and similar tests conducted at UW and UofS over the last few years. Students completed an assignment question in which they were asked to analyze data from a Steiner tunnel test. One of the two required laboratory reports required the students to analyze the cone calorimeter data, present it using the requirements in the relevant ASTM standard [9], and compare the results to others obtained in the two labs. This last comparison allowed them to comment on the effects of operator, equipment, specimen preparation and conditioning. The other laboratory report involved the design of a field fire experiment, which would be conducted in collaboration with a local fire department.

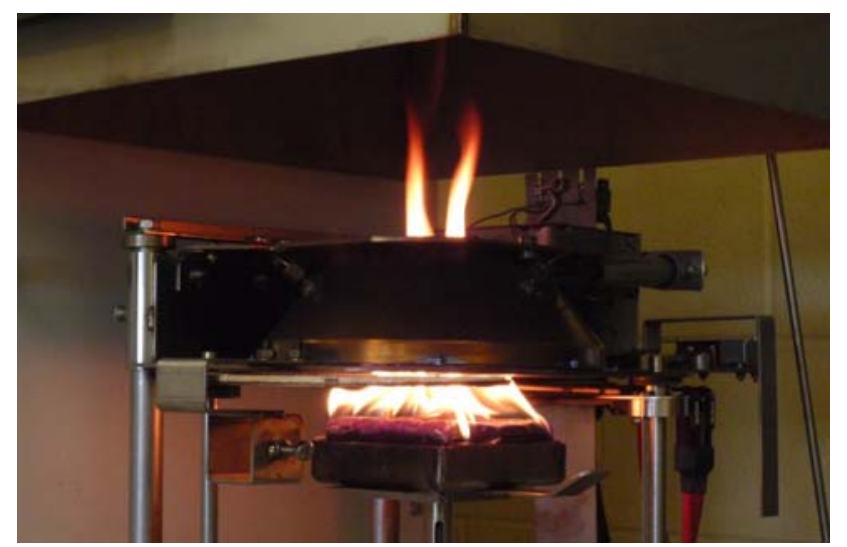

Fig. 1. University of Waterloo Cone Calorimeter.

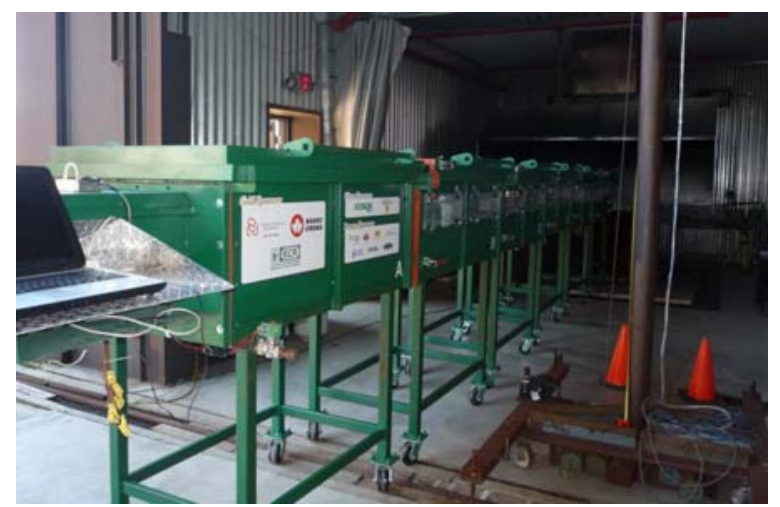

Fig. 2. University of Waterloo Steiner Tunnel.

Intended learning outcomes were developed for all of the UW Fire Safety Engineering graduate courses as part 
of the Ontario Universities Council on Quality Assurance process [10]. The outcomes for ME 770 (Table 3) reflect the expectations that students will learn how to critically evaluate standard fire tests and experimental research, and to communicate with audiences with a wide variety of technical background, from engineers and researchers to code officials and fire department personnel.

Table 3: ME 770 Intended Learning Outcomes.

\begin{tabular}{|c|c|}
\hline \multicolumn{2}{|c|}{ Major Outcomes } \\
\hline 1 & $\begin{array}{l}\text { Have the ability to read, understand, use and } \\
\text { critique scientific literature and codes of practice } \\
\text { at the forefront of the field }\end{array}$ \\
\hline 2 & $\begin{array}{l}\text { Have understanding of the principles and } \\
\text { application of modern instrumentation, } \\
\text { computational methods, experimental design, } \\
\text { performance standards and data analysis and their } \\
\text { application in the field }\end{array}$ \\
\hline 3 & $\begin{array}{l}\text { Understand and appreciate the limitations and } \\
\text { assumptions inherent in computational methods } \\
\text { and experimental data and develop ability to } \\
\text { critically assess and understand their implications } \\
\text { on use of these tools for informed decision } \\
\text { making, development of codes and standards and } \\
\text { other key elements of professional practice }\end{array}$ \\
\hline 4 & $\begin{array}{l}\text { Have proficiency in communicating complex } \\
\text { technical information and scientific concepts to a } \\
\text { variety of audiences via means such as memos, } \\
\text { lab and technical reports, presentations, case } \\
\text { studies, engineering calculations }\end{array}$ \\
\hline \multicolumn{2}{|c|}{ Minor Outcomes } \\
\hline 1 & $\begin{array}{l}\text { Have extensive knowledge and understanding of } \\
\text { mechanical and mechatronics engineering } \\
\text { fundamentals including some or all of } \\
\text { thermodynamics, heat transfer, fluid flow, solids } \\
\text { and materials }\end{array}$ \\
\hline 2 & $\begin{array}{l}\text { Have the ability to recognize current fire science } \\
\text { and engineering problems, formulate questions } \\
\text { and answers and carry out strategies for solving } \\
\text { them even when complex and/or at the forefront } \\
\text { of the emerging discipline or a developing area of } \\
\text { professional practice }\end{array}$ \\
\hline 3 & $\begin{array}{l}\text { Have conducted critical analysis of novel issues } \\
\text { or new applications with arguments to justify } \\
\text { engineering decisions and judgment }\end{array}$ \\
\hline 4 & $\begin{array}{l}\text { Have applied advanced concepts and modelling to } \\
\text { new issues and applications with critical } \\
\text { evaluation and interpretation of their engineering } \\
\text { limitation and significance in the context of } \\
\text { professional practice }\end{array}$ \\
\hline
\end{tabular}

These expectations are also reflected in the course work that students complete. While many graduate and undergraduate engineering courses mainly involve engineering analysis, a relatively minor portion of the evaluation in ME 770 is based on these types of questions, as it is expected that students will acquire the necessary background theory in fire dynamics, heat transfer, fluid mechanics and other topics through other courses. Assignments are worth $25 \%$ of the student's raw grade and about half of the marks are assigned to numerical questions. The other half of the marks are assigned to reviews of experimental research papers and short reports on the continuing relevance of existing test standards in terms of engineering applications. The vast majority of the student's raw grade is based on the laboratory reports (25\%) and a course project (50\%). As the students will have been exposed to all of the course material before they attempt the coursework, it is expected that they should be able to integrate and apply this knowledge in significant depth in their reviews, labs and project reports.

\section{VIDEOCONFERENCE TECHNOLOGY}

Lectures are held in the UW E5 Live classroom in Waterloo (Fig. 1). The facility includes a smart board and projection screens at the front and two additional screens at the back of the classroom. A multi-point videoconferencing system is used, and there can be up to 12 remote participants. Students and the instructor can see both the presenter and slides (Fig. 2), as well as all of the remote participants. Classes are recorded and students can replay lectures at any time during the term that they are enrolled in the course. Course materials are made available to the students through email and the Waterloo LEARN online system.

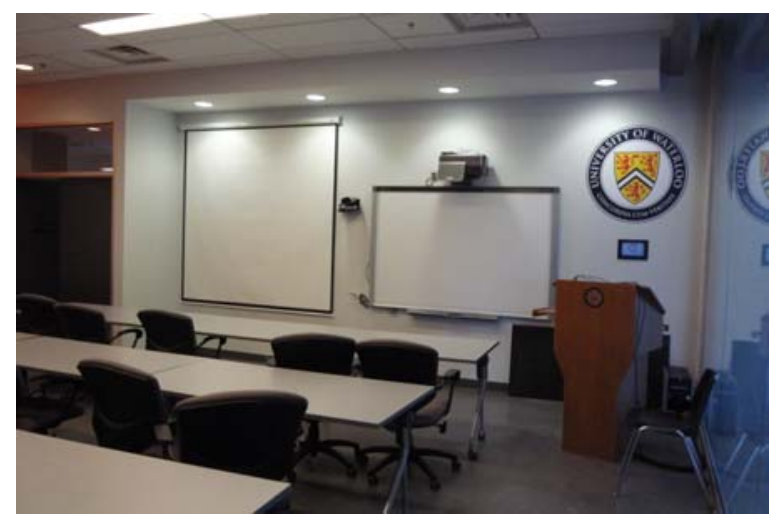

Fig. 1. University of Waterloo E5 Live Classroom.

Students who will be participating by videoconference are currently provided with the following list of minimum requirements for the course: an "up to date" computer with a minimum 1 GB video card running either a 
Windows or Mac operating system; a wired network connection with a minimum upload speed of 1 to 2 Mbps; and a web camera, microphone and speakers (or headset). Prior to the course, students are provided with a link to download the software for their computer (Cisco Jabber Video for TelePresence) from the UW website, along with a login and password. A technician is available to help them test the system prior to the start of classes, and technicians are also available during the week of classes to address any technical difficulties. When lectures are ready to begin, the system contacts the participants and invites them to join the videoconference.

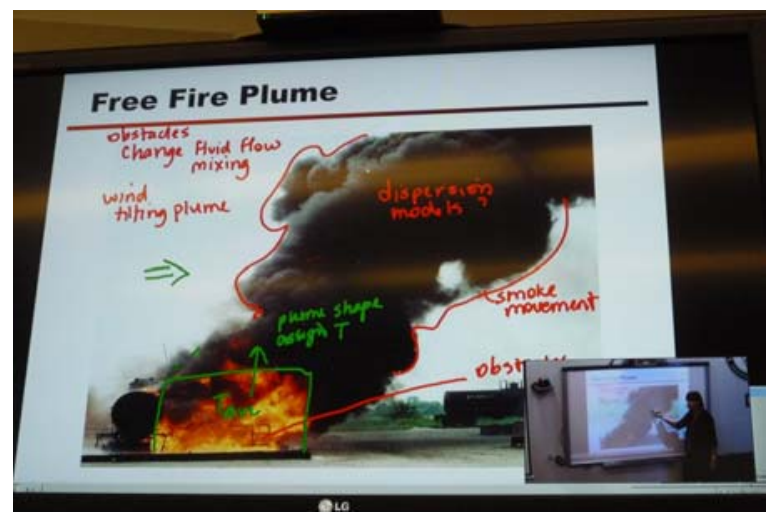

Fig. 2. Example of ME 770 Lecture.

In 2013, six students attended the ME 770 lectures. Two students attended the entire week in Waterloo, while one student split his time between Waterloo and Toronto, where he participated via videoconference. Three students participated via videoconference from their company offices in Vancouver. One of the instructors gave his lectures from Saskatoon, while the other instructor gave her lectures in Waterloo. One of the challenges with the one week format is the different time zones that students and instructors are in. Typically, lectures run between 9:00 am and 5:00 pm Eastern Time, so students on the West Coast must begin class at 6:00 am.

\section{LESSONS LEARNED AND FUTURE WORK}

In general, the videoconference format has been well received by students and faculty. Informal surveys and discussions have indicated that remote students realize that this format may have some disadvantages as compared to attending in person, but it has also made it much easier and less expensive for students to access this specialized graduate program. While some continuing professional education offerings are based on a student watching video or PowerPoint slides on their own, students in the program have expressed a preference for participating in the real time lectures with other students.
While students have an option of completing this and other UW Fire Safety Engineering courses as reading courses by watching the recorded lectures, very few take this route. Students who participate during the week of lectures also comment that they will review the lectures over the term when they complete coursework. From an instructor's point of view, the remote students have been very willing to ask questions and enrich the classroom with the professional experience that they bring to the class. Since the videoconference format allows more practicing engineers to access this and other courses in the program, this format has ultimately been a benefit to the on campus students as well.

The apparent success of the videoconference format invites the question as to whether it may be advantageous to return to the traditional 13 week, 3 hours/week format for lectures. However, practicing engineers in the program have expressed a preference for the one week lecture format, as it is easier to fit into their busy work schedules. In the future, one possibility may be to move to one day of lectures per month. Course presentations are currently held during the week of lectures and are used primarily to get feedback for the presenters from the other students and instructors. In future, the presentation could be moved to a final presentation later in the term. All of these ideas illustrate how present day engineering graduate courses need to balance the needs of on and off campus students, especially with the increasing emphasis on continuing professional education for practicing engineers.

Another issue for off campus students is access to library materials for their course work. The course makes use of ASTM standards and technical papers, some of which may not be easily accessed by those in industry. This was more of an issue when the course began, since in the past few years many university libraries in Canada have begun to subscribe to the ASTM digital library, so that students can download the standards through their university library account. The choice to use mainly ASTM standards is because many international standards cost hundreds of dollars apiece. In terms of other technical information, many fire laboratories have begun to post older technical reports on their websites, which has increased the amount of material that is easily accessible to students. Finally, the move to digital subscriptions for journals by university libraries has also increased access to journals in fire science and other smaller engineering disciplines.

Over the past two years, it has become clear that the minimum hardware and network requirements for students wishing to take the course using the videoconference system should be re-evaluated. Experience has shown that a dedicated web camera/microphone allows remote students to be seen and heard much more clearly than the camera/microphone 
included in a typical notebook computer. Some students access the internet through a wireless connection from home, whereas for the most part a higher speed wired connection, such as would be found on campus or in an office, is necessary. While the quality of the video and sound from web cameras has improved, students have also asked that the laboratory sessions be filmed using a high resolution, dedicated video camera and posted on the course website so that they can more clearly observe the details of the tests.

Discussions are underway with colleagues at other universities to increase the number of fire science related modular graduate courses. One strategy that shows promise is to develop videoconference nodes at partner universities where students and faculty would attend in person. The course would be team taught by the faculty at the partner institutions and students would have the advantage of personal contact with the instructor and students at their node, but also benefit from the instruction and student participation at the other nodes.

Continuation of the modular approach would allow students to share in some lectures, yet also allow custom courses to be developed for different graduate programs. For example, the authors collaborate with textile science faculty at the University of Alberta. Students in the UofA graduate program may not be interested in wall and floor fire tests, but would benefit from a partial course in experimental design and instrumentation. The ME 770 module on this topic could be combined with course material on standard textile test methods for these students. In turn, engineers would also benefit from a shorter module on textile test methods, which would be relevant to building elements such as carpets and curtains, as well as in consumer product regulation (e.g., upholstered furniture).

A one-day Fire Testing Symposium is being planned for May, 2014 using the videoconference node concept to test the above approach. The UW E5 Live facility will serve as the home node, with additional nodes in Edmonton and Ottawa. Speakers, students and other interested parties will attend at each of the three nodes, or at their own office. A more formal survey of students who have taken UW fire safety engineering courses is also planned after the April, 2014 offering of ME 770, in order to obtain feedback on the videoconference technology currently being used, the modular course format, scheduling and logistics, and course content and materials. Of particular interest is the extent to which both on-campus and remote participants feel that students are able to participate fully in the class using the present videoconference technology.

\section{Acknowledgements}

The authors would like to acknowledge those who have assisted in the delivery of ME 770 over the past several years, including Gord Hitchman, Mike Willson, Martha Morales and Steve Hitchman, along with the many students who have served as teaching assistants and lab demonstrators. Financial support from the UW Fire Research Lab and Department of Mechanical and Mechatronics Engineering is gratefully acknowledged.

\section{References}

[1] Underwriters Laboratories, "Residential Furnishings Side By Side”, Video available as of March 14, 2014 from https://www.ul.com/room_fire/room_fire.html.

[2] J.R. Lawson, "Fire Fighter’s Protective Clothing and Thermal Environments of Structural Fire Fighting”, Report NISTIR 5804, Gaithersburg, MD: National Institute for Standards and Technology, 1996. Available as of March 15, 2014 from http://fire.nist.gov/bfrlpubs/fire96/PDF/f96072.pdf

[3] ASTM E 84, Standard Test Method for Surface Burning Characteristics of Building Materials, West Conshohocken, PA: American Society for Testing and Materials, 2013.

[4] Canadian Commission on Building and Fire Codes, National Building Code of Canada, Ottawa, ON: National Research Council, 2005.

[5] Society of Fire Protection Engineers, 2010 Profile on the Fire Protection Engineer, Bethesda, MD, 2010. Available as of March 14, 2014 from http://www.sfpe.org/Portals/sfpepub/docs/pdfs/AboutUs/2010 SFPE Membership Survey with Engineering Level sChart.pdf

[6] S.E. Magnusson et al., “A Proposal for a Model Curriculum in Fire Safety Engineering”, Fire Safety Journal, vol. 25, pp. 1-88, 1995.

[7] M. Woodrow, L. Bisby, and J.L. Torero, “A Nascent Educational Framework for Fire Safety Engineering”, Fire Safety Journal, vol. 58, pp. 180-194, 2013.

[8] Erasmus Mundus International Master of Science in Fire Safety Engineering, Ghent University. Available as of March 14, 2014 from http://www.imfse.ugent.be

[9] ASTM E 1354, Standard Test Method for Heat and Visible Smoke Release Rates for Materials and Products Using an Oxygen Consumption Calorimeter, West Conshohocken, PA: American Society for Testing and Materials, 2013.

[10] Ontario Universities Council on Quality Assurance, “Quality Assurance Framework”, January, 2014. Available as of March 14, 2014 from http://oucqa.ca/ 